\title{
Voltmeter Device
}

National Cancer Institute

\section{Source}

National Cancer Institute. Voltmeter Device. NCI Thesaurus. Code C50058.

A device designed to measure the voltage potential difference between points in a circuit. 